Article

\title{
Electric VTOL Configurations Comparison
}

\author{
Alessandro Bacchini ${ }^{*},+(\mathbb{D})$ and Enrico Cestino ${ }^{\dagger}$ \\ Department of Mechanical and Aerospace Engineering, Politecnico di Torino, 10129 Turin, Italy; \\ enrico.cestino@polito.it \\ * Correspondence: alessandro.bacchini@polito.it; Tel.: +39-339-5348624 \\ + These authors contributed equally to this work.
}

Received: 21 December 2018; Accepted: 22 February 2019; Published: 28 February 2019

\begin{abstract}
In the last ten years, different concepts of electric vertical take-off and landing aircrafts (eVTOLs) have been tested. This article addresses the problem of the choice of the best configuration. VTOLs built since the fifties are presented and their advantages, disadvantages, and problems are discussed. Three representative eVTOLs, one for each main configuration, are compared on five main parameters and three reference missions. The parameters are disk loading, total hover time, cruise speed, practical range, and flight time. The performance of the eVTOLs on the urban, extra-urban, and long-range mission is evaluated computing the time and energy required. The results show that the best configuration depends on the mission. The multirotor is more efficient in hover. The vectored thrust jet is more efficient in cruise and has a higher range. The lift + cruise is a compromise.
\end{abstract}

Keywords: electric VTOL configurations; VTOL design; aircraft design

\section{Introduction}

Electric vertical take-off and landing aircrafts (eVTOLs) are being built and tested, and their configurations vary from hover bikes to electric ducted fans. In 2010, Moore [1] presented the NASA Puffin electric tailsitter VTOL concept and highlighted the potential of electric propulsion to enable cheap, quiet, and reliable short-range VTOLs. That same year the company ZeeAero, now Kitty Hawk [2], was founded by Kroo with the aim of building an eVTOL flying car. From that moment on, many researchers, companies, and startups started to work on eVTOLs. Now, most of the major aircraft companies are directly developing their own electric VTOL or have subsidiaries doing it. More than 130 electric VTOL concepts have been proposed [3] and venture capitalists have invested more than 1 billion dollars into promising eVTOL startups [4]. Moore and his colleagues have worked on the idea of on-demand air mobility [5,6], hybrid eVTOLs [7], the advantages of electric propulsion compared to internal combustion and gas turbines [8], and the distributed electric propulsion of the X-57 Sceptor [9]. McDonald has worked on electric propulsion modeling for conceptual design [10] and developed the OpenVSP design tool.

Most of the research has been conducted by private companies. Uber has hired both Moore and McDonald and is trying to build, with its program Uber Elevate, the infrastructure for eVTOLs [11]. Kitty Hawk, Lilium, Joby Aviation, and E-Hang are four of the startups developing electric VTOLs. Kitty Hawk has developed and is now testing two vehicles: Cora, the lift + cruise air taxi and the Flyer, a hoverbike [12]. Lilium is a German startup that is building an electric ducted fan eVTOL. They have flown many prototypes including a two-seater jet and are now developing a five-seater air taxi [13]. Joby Aviation has performed tests on electric propulsion and is building an eVTOL prototype [14]. E-Hang is a Chinese company manufacturing quadrotor UAVs that has built and tested, with humans on board, the E-Hang 184 passenger drone [15].

This article tries to understand which is the best eVTOL design, presenting and discussing all the different configurations, from the first developed in the fifties and sixties to the present eVTOL 
configurations. Then, the performances of the three main eVTOL configurations are evaluated and compared using data from existing prototypes.

\section{Materials and Methods}

During the fifties and sixties, after the development of the helicopter, a great research effort was put into the development of a machine able to fly as fast as an airplane and able to take off and land vertically like a helicopter, the VTOL aircraft. Many different configurations were tested, and the only VTOL put into operation was the Harrier. Years later it was followed by the Yak-38, the V-22, and the F-35. The power plants available to the designers were piston engines and jets. The efficiency of these engines grows with their size, this means that having multiple power plants on the aircraft means a reduction in efficiency and power at a fixed total mass. Instead, electric motors have negligible variation in efficiency at different dimensions. At that time, choosing between using the same power plant for hover and cruise, or having two different power plants was the main design decision. Different configurations were tested by different companies during the span of two decades. The main configurations are listed following the criteria used by the American Helicopter Society [16] and the advantages and disadvantages of each configuration [17] are discussed.

The VTOLs that use the same propulsion system for hover and forward flight can rotate the direction of the thrust in different ways. The tail-sitters rotate the entire aircraft. They are conceptually simple but difficult and risky to control [17]. The Harrier configuration is called vectored thrust because it can orientate mechanically the direction of the thrust. In the beginning, vectored thrust VTOLs, like the first Harrier prototypes and the Bell X-14, suffered from suck-down, engine gyroscopic effects, and hot gas re-ingestion $[17,18]$. When these problems were solved, the Harrier became the first operational VTOL attack aircraft [19]. The deflected-slipstreams use flaps to deflect the slipstream of the propellers. The Ryan VZ3 achieved excellent STOL performances but no VTOL capabilities [17]. The tilt-jets rotate the entire nacelle of the jet. The tiltrotors like the V-22 Osprey and the Agusta Westland AW609 tilt the entire rotor. They have hover performances comparable to the ones of a helicopter with the advantage of not having the retreating blade problem in forward flight. They are complex machines. The tilt-wings rotate the entire wing, the engines and the propellers as a single piece. Rotating the wing in hover avoids the impinging of the propeller slipstream on it, a problem that reduces the thrust in the hover of tiltrotors. The lift produced by the wing is augmented, at high angles of attack, by the blowing effect of the propellers. Tilt-wings of the fifties and sixties suffered from control problems due to low pitch control power, were mechanically complex, and the loss of an engine could cause catastrophic roll upset [17]. NASA's Greased Lightning new tilt-wing hybrid diesel-electric VTOL demonstrated that these problems are solvable with electric motors and electronic control [20]. Tilt-ducts use ducted fans which have the advantage of reducing blade tip loss and producing higher thrust for the rotor diameter. The Doak VZ-4 and the Bell X-22 proved the feasibility of the concept but struggled with control problems [17].

Other VTOLs like the Short SC.1, the Dassault Balzac V, and the Mirage III V had an additional power plant for hover. The Mirage III V is the fastest VTOL on record, reaching Mach 2.04 in September 1966. The VTOL capability was achieved adding vertical jets in the fuselage, which reduced the useful load fraction $[17,21]$.

The lift + lift/cruise VTOLs use one set of engines for lift only and another set of engines for both lift and cruise. The Soviet Yak 38 is one of these VTOLs, it vectored the thrust of the main engine and used two additional engines behind the cockpit for hover. The tip-jets are a kind of compound autogyros that use a rotor powered by jets at the tip of the blade, propellers for horizontal thrust and a wing to generate lift. The ejector VTOLs eject high-pressure engine efflux into a channel called the augmentor causing additional ambient air to accelerate through the channel and mix with the engine exhaust. The Lockheed XV-4A Hummingbird applied this concept but tests on the prototypes showed results inferior to laboratory tests, incomplete mixing, and ram drag [17]. The fan VTOLs have one or more additional fans buried in the wings or fuselage powered by the main engine. The F- 35 has 
a fan behind the cockpit which provides, with the nozzle of the main engine swiveled, the thrust required for hover. The Rayan XV-5A had two fans-in-wing powered by the exhaust gases of its two turbojets. The two prototypes crashed during transition because of the slow control response and narrow transition corridor [17]. The last VTOL category is the compound helicopter which uses a rotor to hover and has a propeller for forward flight.

In recent years many companies and startups have started developing and testing different electric VTOLs. The website Electric VTOL News [22], published by the Vertical Flight Society, classifies eVTOLs in the following categories:

- $\quad$ Vectored Thrust

- $\quad$ Lift + Cruise

- Wingless

- $\quad$ Hoverbikes

- eHelos

The vectored thrust eVTOLs have a wing for an efficient cruise and use the same propulsion system for both hover and cruise. The Lilium Jet, the Aurora LightningStrike, and the Joby S2 and S4 are in this category (Figure 1). The Lilium Jet is a tilt duct able to increase the lift coefficient of the wing, during the transition, sucking air from the upper surface of the wing and pushing it down with the electric jets. The Aurora LightningStrike is a tilt-wing with fans-in-wing. The Joby S2 is a tilt prop. The main difference between eVTOLs in this category is whether they have fans or propellers.
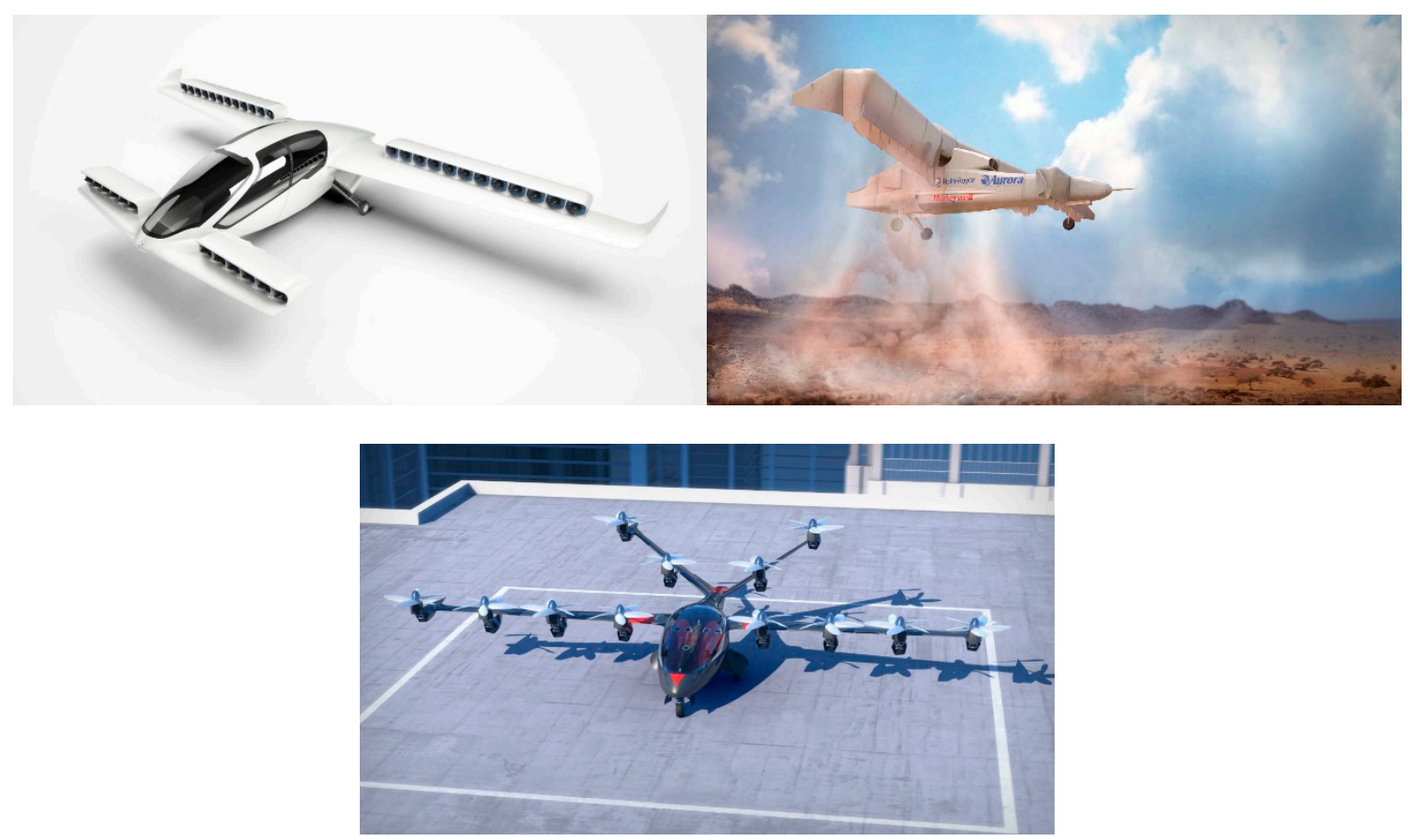

Figure 1. Vectored thrust electric vertical take-off and landing aircrafts (eVTOLs): Lilium Jet [13], Aurora Lightning Strike [23], Joby S2 [24].

The lift + cruise eVTOLs have a wing for an efficient cruise, like vectored thrust eVTOLs, but they use two different propulsion systems for hover and cruise flight. The ZeeAero Z-P2, the Kitty Hawk Cora, and the Aurora Flight Sciences eVTOL are in this category (Figure 2). 

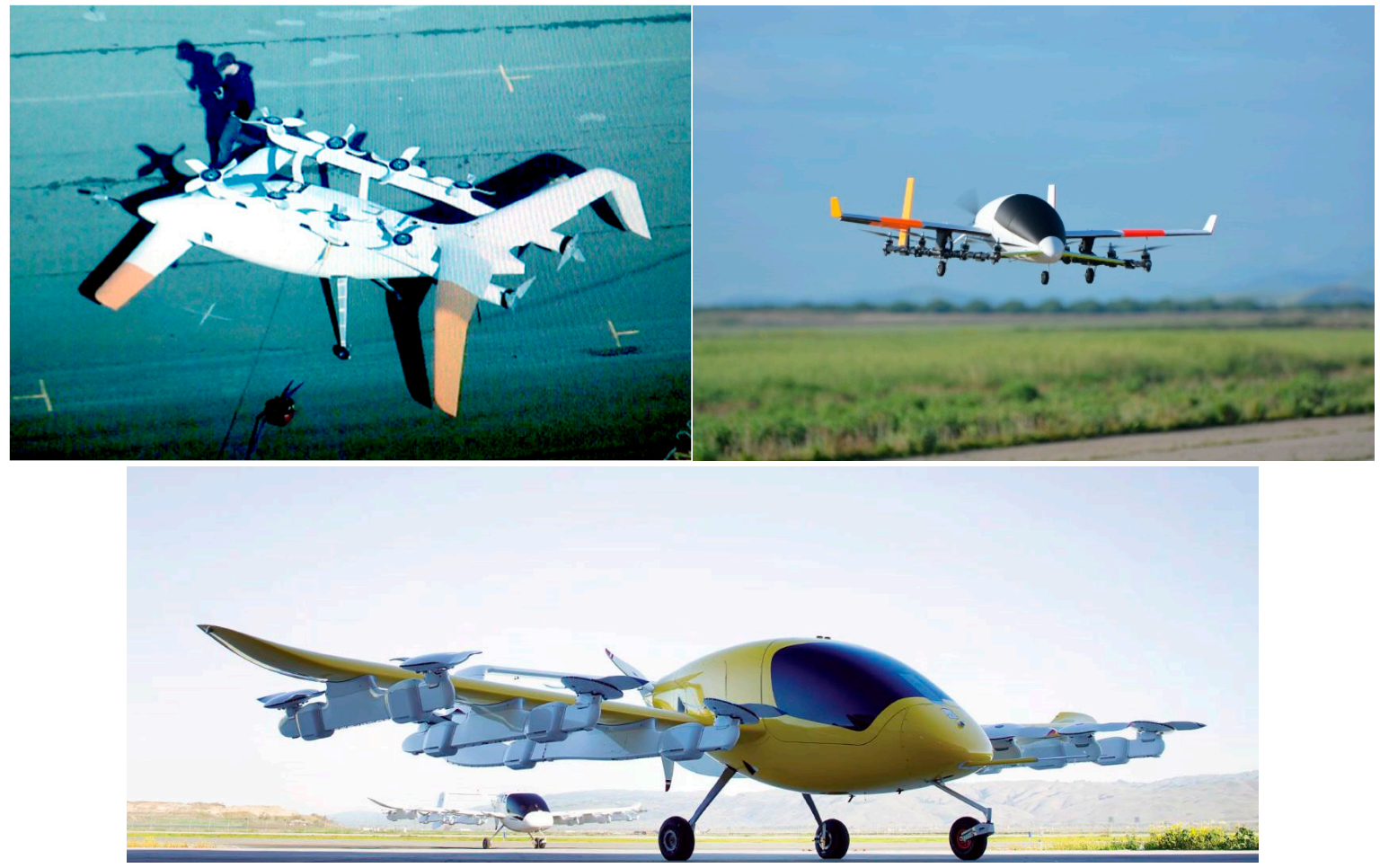

Figure 2. Lift + cruise eVTOLs: ZeeAero Z-P2 [25], Aurora Flight Sciences eVTOL [26], Kitty Hawk Cora [27]:

The wingless eVTOLs are multirotors. They have large disk actuator surface which makes them efficient in hover, but they do not have a wing for an efficient cruise. These vehicles are suited for short-range operations in cities where they can fly over traffic jams. Two VTOLs in this class are already in the certification phase: The E-Hang 184 and the Volocopter 2X (Figure 3).

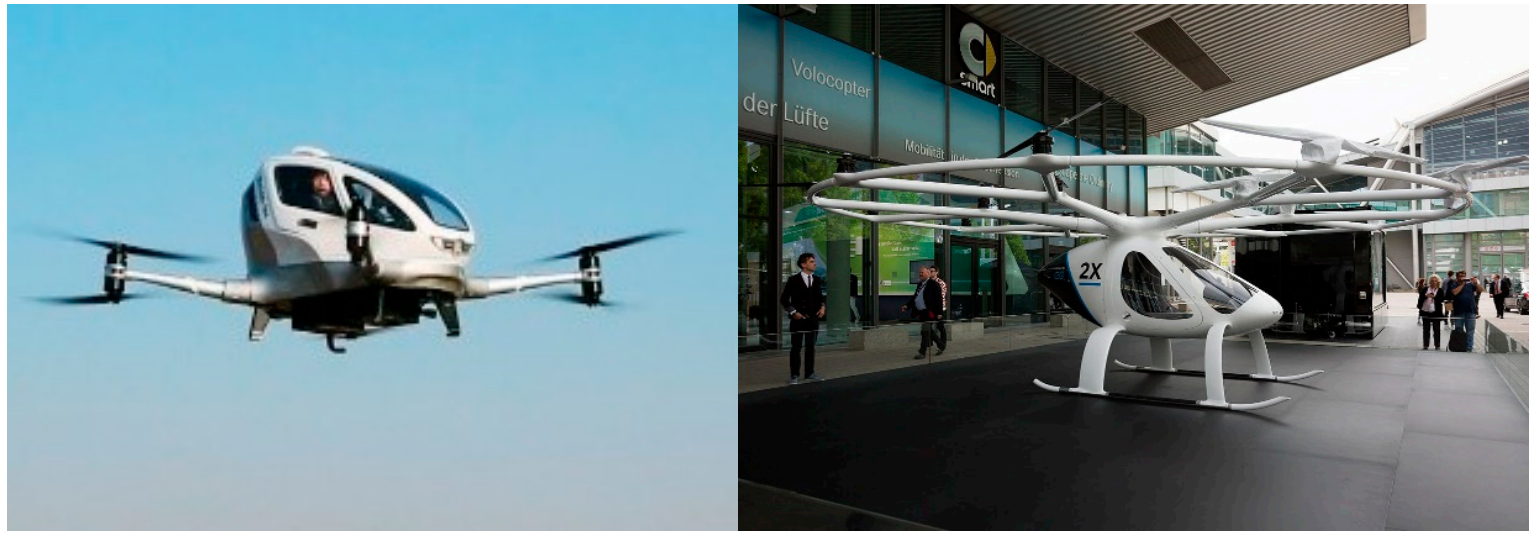

Figure 3. Wingless eVTOLs: E-Hang 184 [28], Volocopter 2X [29].

Hoverbikes are multirotors that can be flown like a motorbike. The pilot sits on a saddle or is standing. An example is the prototype built and flown by Kitty Hawk (Figure 4). 


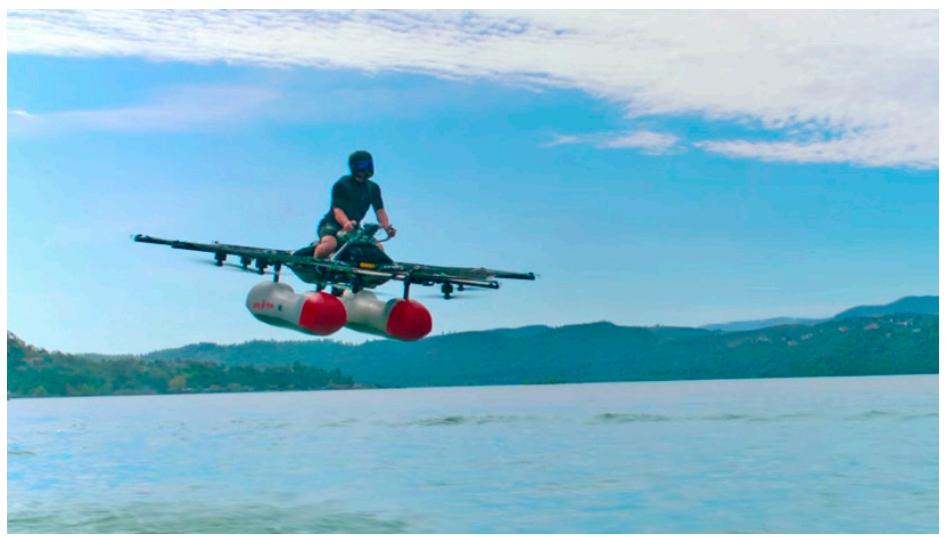

Figure 4. Kitty Hawk hoverbike [30].

eHelos are electrical conventional helicopters. An example is the Aquinea Volta (Figure 5).

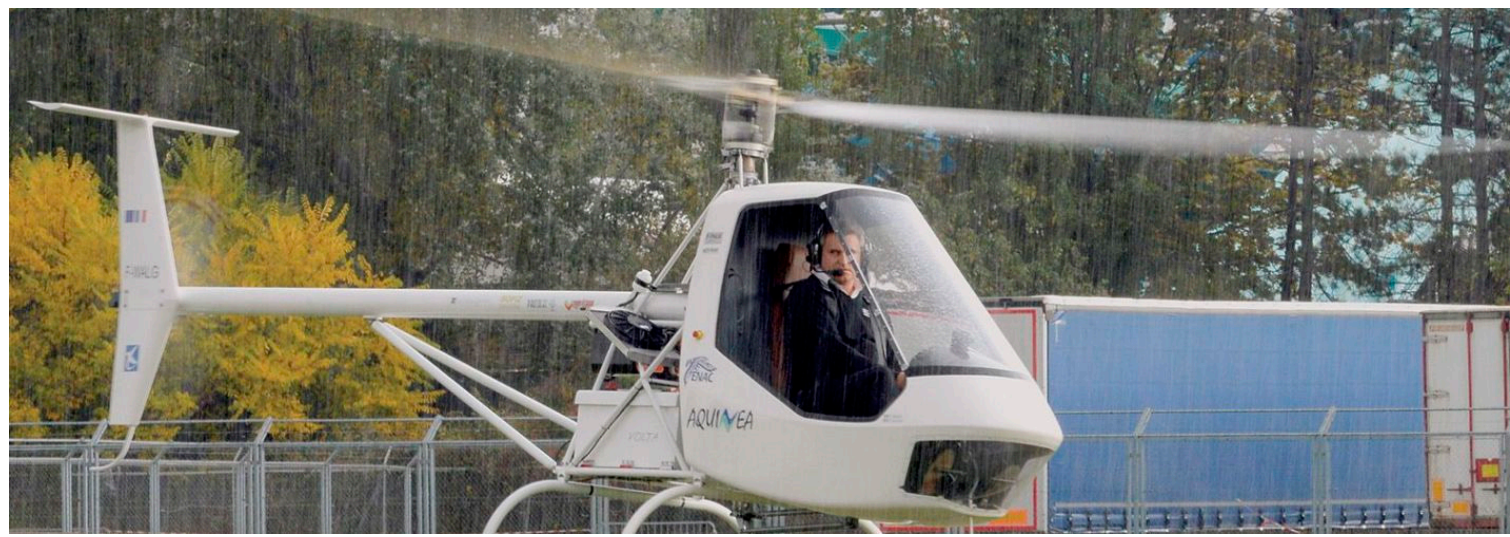

Figure 5. Aquinea Volta [31].

The E-Hang 184, the Kitty Hawk Cora, and the Lilium Jet have been chosen as the reference for the comparison of the three main eVTOL categories. Their performances have been computed using analytical methods [32] such as the disk actuator theory [33] to evaluate hover performances, Breguet's equation for electric flight [34] to compute the theoretical range, empirical methods to evaluate the drag of the eVTOL from the Hoerner's book [35] and standard drag, power, efficiency considerations.

The comparison has been performed evaluating five parameters and computing the energy and time required to perform three reference missions. The five parameters are disk loading, total hover time, cruise speed, practical range, and flight time. The reference missions are:

- $\quad 7 \mathrm{~km}$ urban mission

- $\quad 30 \mathrm{~km}$ extra-urban mission

- $\quad 100 \mathrm{~km}$ long-distance mission

\section{Results}

\subsection{Wingless Multirotor Configuration}

To present the performances of the wingless multirotor configuration, the e-Hang 184 data [15] has been used and its performance has been evaluated. Figure 6 shows the E-Hang 184 . 

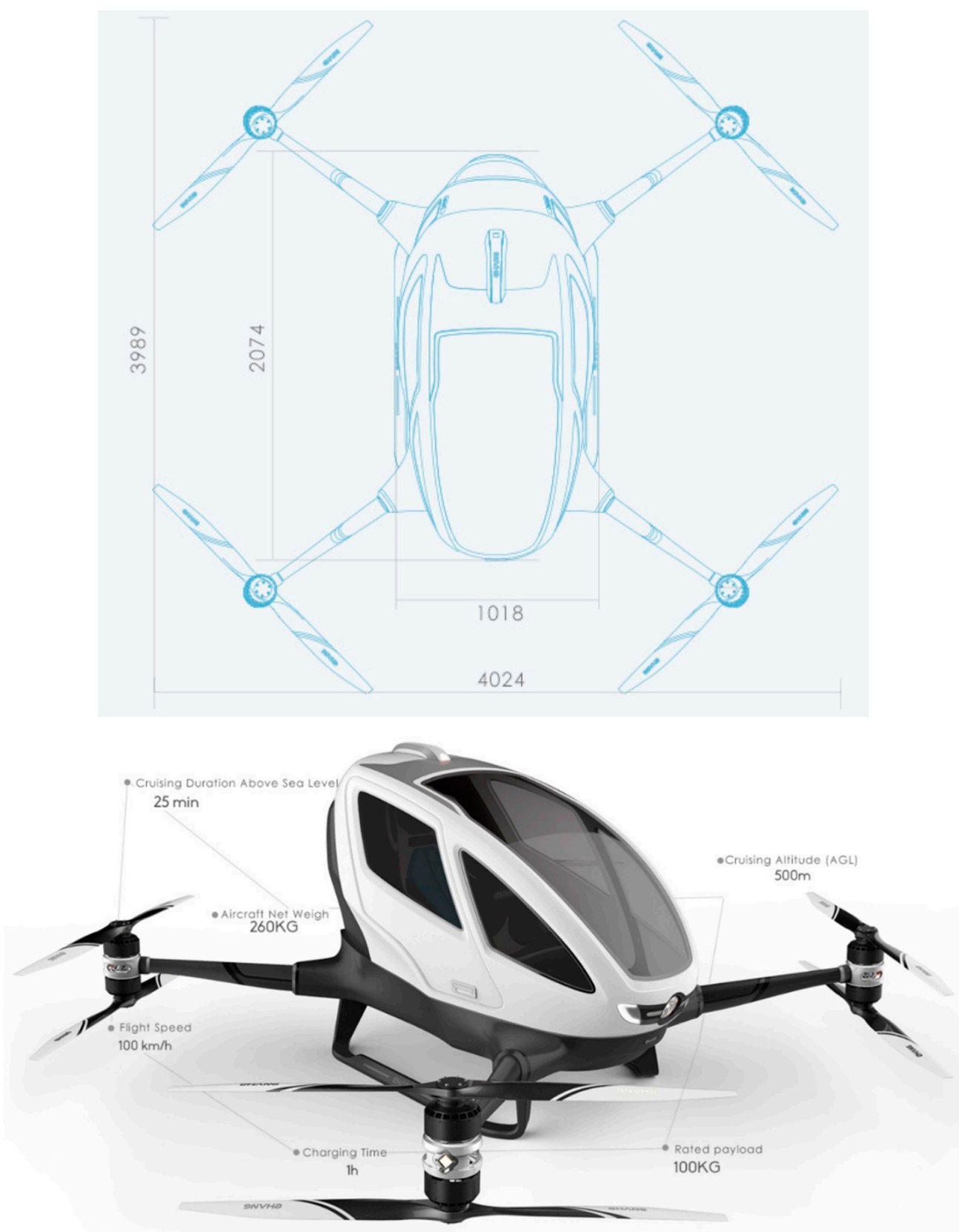

Figure 6. E-Hang 184 specs and dimensions, from E-Hang website [15]. Dimensions in the top view are in millimeters.

Data of the e-Hang 184 configuration, found in their website [15], is presented in Table 1.

Table 1. E-Hang 184 specifications from E-Hang website [15].

\begin{tabular}{cc}
\hline Maximum total power & $152 \mathrm{~kW}$ \\
Number of motors & 8 \\
Total battery energy & $14.4 \mathrm{kWh}$ \\
Propeller diameter & $1.6 \mathrm{~m}$ \\
Net weight & $260 \mathrm{~kg}$ \\
Total flight time & $25 \mathrm{~min}$ \\
Rated payload weight & $100 \mathrm{~kg}$ \\
Average flight speed & $100 \mathrm{~km} / \mathrm{h}$ \\
\hline
\end{tabular}


The estimated values of geometry, battery, mass balance, and hover performances are presented in Table 2.

Table 2. E-Hang 184 data computed with Figure 6 and Table 1 data.

\begin{tabular}{lll}
\hline Geometry & & \\
\hline $\begin{array}{l}\text { Propeller area } \\
\text { Total disk actuator area }\end{array}$ & $2.01 \mathrm{~m}^{2}$ & $\begin{array}{l}\text { Computed } \\
\text { Computed }\end{array}$ \\
\hline Battery & $8.04 \mathrm{~m}^{2}$ & \\
\hline Energy density & & \\
Specific power & $157 \mathrm{Wh} / \mathrm{kg}$ & Assumed [36] \\
Max power & $735 \mathrm{~W} / \mathrm{kg}$ & Assumed [36] \\
\hline Mass balance & $67 \mathrm{~kW}$ & Computed \\
\hline Battery mass & & \\
Empty weight & $92 \mathrm{~kg}$ & Computed \\
Payload weight & $168 \mathrm{~kg}$ & Computed \\
\hline Hover performances & $100 \mathrm{~kg}$ & E-Hang data \\
\hline Average power consumption & & \\
Power required to hover & $34.6 \mathrm{~kW}$ & Computed \\
Energy required for 1 min of hover & $47 \mathrm{~kW}$ & Computed \\
Total hover time & $0.79 \mathrm{kWh}$ & Computed \\
Disk loading & $440.5 \mathrm{~min}$ & Computed \\
\hline
\end{tabular}

The battery mass has been computed as total energy divided by energy specific density. The energy specific density and specific power have been assumed equal to the values of the Tesla Model S battery pack [36]. This assumption has been made because these batteries are used in a consumer product in a high-power application. They have demonstrated the ability to work after years and hundreds of life cycles, in harsh environments like Norway. Li-ion batteries for power applications have specific energy ranging from 100 to $250 \mathrm{Wh} / \mathrm{kg}$ [34,37] and specific power from 700 to $1300 \mathrm{~W} / \mathrm{kg}$ [37]. The assumed values are at pack level, they consider the additional weight of casing, connections, and thermal management system. The energy density and specific power of the batteries used for eVTOLs might be better than the assumed values. This conservative assumption means that the batteries will be able to provide enough power for takeoff and landing even after years of utilization. As batteries age, the energy they can store and the maximum power they can provide decrease [37,38]. For electric cars, this means that the total range decreases. For eVTOLs, designed to be able to take off with maximum battery power at the beginning of the life of the battery, this might mean not having enough power to take off after a few years of service.

The average power consumption has been computed dividing the total energy by the total time of flight. The power required to hover, $\mathrm{P}$, has been computed with the disk actuator theory modified for coaxial rotors [39]:

$$
P=k_{\text {int }} \frac{T^{\frac{3}{2}}}{2 \sqrt{\rho A}}
$$

where $T$ is the thrust or the weight of the vehicle, $\rho$ is the air density at sea level $\left(1.225 \mathrm{~kg} / \mathrm{m}^{3}\right), A$ is the disk actuator area of the vertical thrust system, in this case, the area of the four coaxial rotors, and $k_{i n t}$ is the interference factor. $k_{i n t}$ varies from 1 for zero interference to $\sqrt{2}$ for maximum interference corresponding to the case of two rotors corotating in the same plane. The value selected is 1.26 for rotors operated at balanced torque with the lower rotor operating in the fully developed wake of the upper rotor [39].

The power required to hover, $42.7 \mathrm{~kW}$, is different from the average power consumption specified by the producer, $34.6 \mathrm{~kW}$ (Table 1), because the power required in cruise is less than in hover due to 
the lift produced by the vehicle and to the reduction in induced drag [39-41]. The total hover time found is $20.5 \mathrm{~min}$.

The electric motors have been sized to ensure the safety of the vehicle in case of failure. Each coaxial rotor couple is a failure redundant system. The two rotors are driven by two different motors. When one motor fails, the propeller connected to it stops and the propeller connected to the undamaged motor of the couple provides the entire thrust normally provided by the coaxial rotor couple. To evaluate the power required for this contingency scenario, the standard disk actuator theory has been used [32,33]:

$$
P=\sqrt{\frac{T^{3}}{2 \rho A}}
$$

where $T$ is the thrust and $A$ is the disk actuator area of the single operative propeller. The thrust considered is a quarter of the weight of the vehicle multiplied by a 1.3 margin factor for maneuver. The power found is $17.5 \mathrm{~kW}$ per motor, while the maximum power per motor specified by E-Hang's website [15] is $19 \mathrm{~kW}$. This value has been found by dividing the total power, $152 \mathrm{~kW}$ in Table 1, by 8 , the total number of motors.

\subsection{Lift + Cruise Configuration}

To present the performances of the lift + cruise configuration, the Kitty Hawk Cora's data has been used (Figure 7 and Table 3).
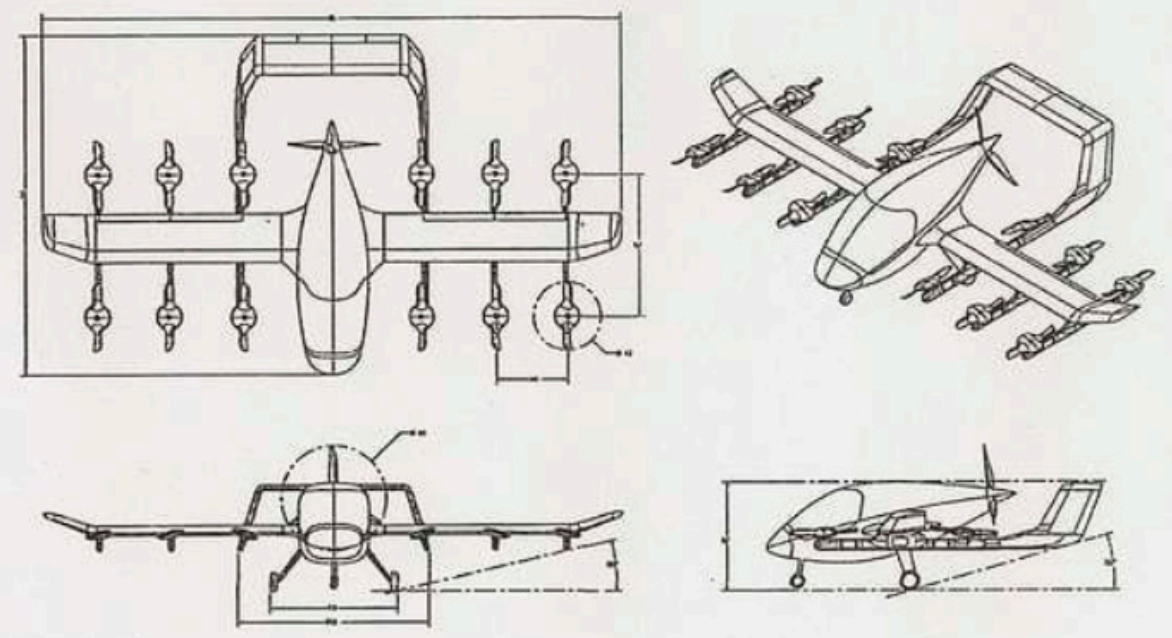

Figure 7. Kitty Hawk Cora geometry [27].

Table 3. Kitty Hawk Cora specifications from Kitty Hawk's website [2].

\begin{tabular}{ccc}
\hline Wingspan & $11 \mathrm{~m}$ & Website data [2] \\
Wing chord & $1 \mathrm{~m}$ & Estimated from Figure 7 \\
Wing surface & $10 \mathrm{~m}^{2}$ & Website data [2] \\
Number of lift fans & 12 & From Figure 7 \\
Lift propeller diameter (external) & $1.3 \mathrm{~m}$ & Estimated from Figure 7 \\
Lift propeller diameter (hub) & $0.5 \mathrm{~m}$ & Estimated from Figure 7 \\
Cruise propeller diameter & $2 \mathrm{~m}$ & Estimated from Figure 7 \\
Range & $100 \mathrm{~km}$ & Website data [2] \\
Flight time (with 10 min reserve) & $19 \mathrm{~min}$ & Website data [2] \\
Speed & $180 \mathrm{~km} / \mathrm{h}$ & Website data [2] \\
Passenger cargo capacity & $181 \mathrm{~kg}$ & Website data [27] \\
Rear landing gear-tail angle & $15.9^{\circ}$ & Estimated from Figure 7 \\
Fuselage-wing angle & $12.4^{\circ}$ & Estimated from Figure 7 \\
\hline
\end{tabular}


Table 3 shows the Kitty Hawk Cora specifications. With this data, the propeller area has been computed and is presented in Table 4.

Table 4. Kitty Hawk Cora propeller area.

\begin{tabular}{lll}
\hline Propeller area (external, single propeller) & $1.3 \mathrm{~m}^{2}$ & Computed \\
Propeller area (internal, single propeller) & $0.2 \mathrm{~m}^{2}$ & Computed \\
Circular crown area (single propeller) & $1.1 \mathrm{~m}^{2}$ & Computed \\
Total disk actuator area & $13.6 \mathrm{~m}^{2}$ & Computed \\
\hline
\end{tabular}

The mass and battery data of the Kitty Hawk eVTOL are listed in Table 5. The total mass of the vehicle is $1224 \mathrm{~kg}$ as specified in [42]. The battery mass has been estimated computing the minimum power required to hover $P$. This is given by the disk actuator Equation (2), where the thrust, $T$, is the weight of the vehicle, $\rho$ is the air density at sea level $\left(1.225 \mathrm{~kg} / \mathrm{m}^{3}\right)$, and $A$ is the disk actuator area of the vertical thrust system.

Table 5. Kitty Hawk Cora mass and battery data.

\begin{tabular}{lll}
\hline Total mass & $1224 \mathrm{~kg}$ & Data [27] \\
Power required to hover & $228 \mathrm{~kW}$ & Computed \\
Battery energy specific density & $157 \mathrm{Wh} / \mathrm{kg}$ & Assumed [36] \\
Battery power density & $735 \mathrm{~W} / \mathrm{kg}$ & Assumed [36] \\
Minimum battery mass & $310 \mathrm{~kg}$ & Computed \\
Battery mass & $400 \mathrm{~kg}$ & Assumed \\
Total battery energy & $63 \mathrm{kWh}$ & Computed \\
Battery mass to total mass ratio & $33 \%$ & Computed \\
\hline
\end{tabular}

The hover performances are listed in Table 6 . The gravity acceleration $g=9.8 \mathrm{~m} / \mathrm{s}^{2}$ has been used. The energy required to hover for one minute is computed multiplying the power required to hover by $60 \mathrm{~s}$ and the total hover time is computed dividing the total energy available by the power required to hover.

Table 6. Kitty Hawk Cora hover performances.

\begin{tabular}{lll}
\hline Energy for 1 min of hover & $3.8 \mathrm{kWh}$ & Computed \\
Total hover time & $16.5 \mathrm{~min}$ & Computed \\
Disk loading & $880 \mathrm{~N} / \mathrm{m}^{2}$ & Computed \\
\hline
\end{tabular}

Comparing it to the E-Hang 184, the Kitty Hawk Cora requires over four times the energy for one minute of hover, has double the disk loading, and has a lower total hover time. The aerodynamic properties of the Cora vehicle have been estimated using the lifting line theory, adding the additional resistance of the pylons and propellers for the vertical takeoff. For the lifting line procedure, the airfoil's lift slope coefficient and zero lift angle have been assumed $5.34 \mathrm{rad}^{-1}$ and $-3.26^{\circ}$. These values have been found selecting the airfoil NLF(1)-0115 [43,44] and using the software Xfoil [45] for the computations. The aerodynamic drag of the wing and the horizontal tail are computed integrating the airfoil sections contribution. The drag of the other components is estimated using the parameters listed in Table 7. 
Table 7. Kitty Hawk Cora geometry data used to compute the drag.

\begin{tabular}{|c|c|c|}
\hline Fuselage & & \\
\hline Length & $4.8 \mathrm{~m}$ & Estimated from Figure 7 \\
\hline Diameter & $1.5 \mathrm{~m}$ & Estimated from Figure 7 \\
\hline Wet surface & $13 \mathrm{~m}^{2}$ & Computed \\
\hline \multicolumn{3}{|l|}{ Horizontal tail } \\
\hline Surface & $2 \mathrm{~m}^{2}$ & Estimated from Figure 7 \\
\hline Thickness to chord ratio & 0.12 & Assumed \\
\hline Chord & $0.75 \mathrm{~m}$ & Estimated from Figure 7 \\
\hline \multicolumn{3}{|l|}{ Vertical tail } \\
\hline Sweep & $10^{\circ}$ & Estimated from Figure 7 \\
\hline Thickness to chord ratio & 0.12 & Assumed \\
\hline Height & $1 \mathrm{~m}$ & Estimated from Figure 7 \\
\hline Chord & $0.75 \mathrm{~m}$ & Estimated from Figure 7 \\
\hline Wet surface & $1.5 \mathrm{~m}^{2}$ & Computed \\
\hline Number of vertical tails & 2 & From Figure 7 \\
\hline \multicolumn{3}{|l|}{ Pylons } \\
\hline Length & $3.5 \mathrm{~m}$ & Estimated from Figure 7 \\
\hline Width & $0.16 \mathrm{~m}$ & Estimated from Figure 7 \\
\hline Height & $0.36 \mathrm{~m}$ & Estimated from Figure 7 \\
\hline Wet surface & $3.76 \mathrm{~m}^{2}$ & Computed \\
\hline Number of pylons & 6 & From Figure 7 \\
\hline \multicolumn{3}{|l|}{ Propellers } \\
\hline Length & $1.3 \mathrm{~m}$ & Estimated from Figure 7 \\
\hline Diameter & $0.3 \mathrm{~m}$ & Estimated from Figure 7 \\
\hline Wet surface & $0.8 \mathrm{~m}^{2}$ & Computed \\
\hline Number & 12 & From Figure 7 \\
\hline \multicolumn{3}{|l|}{ Landing gear } \\
\hline Tire width & $0.15 \mathrm{~m}$ & Estimated from Figure 7 \\
\hline Tire height & $0.3 \mathrm{~m}$ & Estimated from Figure 7 \\
\hline Surface & $0.045 \mathrm{~m}^{2}$ & Computed \\
\hline
\end{tabular}

The fuselage drag is computed using [46]:

$$
C_{D 0}=\sum C_{f} F Q\left[S_{w e t} / S_{r e f}\right]
$$

where $C_{f}$ is given by:

$$
C_{f}=\frac{0.455}{\left(\log R e_{c}\right)^{2.58}\left(1+0.144 M^{2}\right)^{0.65}}
$$

for turbulent flow, and by:

$$
C_{f}=\frac{1.328}{\sqrt{R e_{c}}}
$$

for laminar flow, $F$ is the form factor given by:

$$
F=1+2.2\left(\frac{d}{l}\right)^{1.5}-0.9\left(\frac{d}{l}\right)^{3}
$$

and $Q$ is the interference factor set at 1 . The flow is assumed to be $20 \%$ laminar and $80 \%$ turbulent.

The same procedure has been followed for the vertical tail, computing the form factor, $F$, by

$$
F=\left(F^{*}-1\right) \cos ^{2} \Delta_{0.5 c}+1
$$


where $F^{*}=1+3.52(t / c)$ and $\Delta_{0.5 c}$ is the sweep angle at $50 \%$ of the chord. The interference factor, $Q$, is set at 1.2 for the vertical tail.

The drag of the pylons supporting the vertical lift propellers and the drag of the vertical lift propellers has been computed as the base drag of a 3D body [35] (pp. 3-19). The drag coefficient is computed as:

$$
C_{D B}=\frac{0.029}{\sqrt{C_{f}}}
$$

then it is scaled to the reference surface, corresponding to the wing surface:

$$
C_{D B 0}=\frac{S_{\text {front }}}{S_{\text {ref }}} C_{D B}
$$

Equations (8) and (9) have been applied for both the pylons supporting the vertical lift propellers and for the vertical lift propellers using their different geometries and different friction coefficients. The drag of the landing gear is computed supposing a $C_{D 0}$ of 0.25 as suggested in [35] and scaling it from the wheel surface to the reference surface.

The interference drag between the wing and fuselage has been added using the following equation [35]:

$$
C_{D}=\left(0.8\left(\frac{t}{c}\right)^{3}-0.0003\right) \frac{c^{2}}{S_{r e f}}
$$

The drag polar of the Cora vehicle computed is:

$$
C_{D}=0.0438+0.0294 \cdot C_{L}^{2}
$$

The speed of maximum $L / D$ and the maximum $L / D$ are given by [47]:

$$
\begin{gathered}
V_{\max \frac{L}{D}}=\sqrt{\frac{2}{\rho_{\infty}} \sqrt{\frac{k}{C_{D 0}}} \frac{W}{S}} \\
\frac{L}{D}_{\text {max }}=\sqrt{\frac{C_{D 0}}{k}}
\end{gathered}
$$

where $C_{D 0}$ and $k$ are the parameters of the drag polar. This gives a speed of maximum $L / D$ of $145 \mathrm{~km} / \mathrm{h}$ and a maximum $L / D$ of 13.9. The theoretical range, given by [32]:

$$
R=E^{*} \cdot \eta_{\text {total }} \cdot \frac{1}{g} \cdot \frac{L}{D} \cdot \frac{m_{\text {battery }}}{m}
$$

is $200 \mathrm{~km}$. Limiting the depth of discharge to $70 \%$, improving the cruise speed to save time to $180 \mathrm{~km} / \mathrm{h}$, and considering takeoff and landing the range decreases to $107 \mathrm{~km}$. The flight time is $36 \mathrm{~min}$. These results are in accordance with the performances specified by the producer of $180 \mathrm{~km} / \mathrm{h}$ cruise speed and $19 \mathrm{~min}$ flight time plus $10 \mathrm{~min}$ of reserves (Table 3). The depth of discharge of the battery has been limited to $70 \%$ because Li-ion batteries lifetime depends on the depth of discharge at which they are subjected [37]. A 70\% depth of discharge gives a good amount of energy preserving the lifetime of the battery. The energy required for takeoff, landing, and transition is $6.3 \mathrm{kWh}$, which corresponds to $1 \mathrm{~min}$ and $40 \mathrm{~s}$ of hover. The power required for the cruise is given by:

$$
P_{r e q}=\frac{D \cdot v}{\eta}
$$


where $D$ is the aerodynamic $\operatorname{drag}, D=\frac{1}{2} \rho_{\infty} S v^{2} C_{D}, v$ is the flight speed and $\eta$ is the total efficiency of the power electronics and propeller which has been assumed $75 \%$.

The angle of attack in cruise is 8 degrees. This seems reasonable because, as seen in the drawings, the angle between the wing and the fuselage is 12 degrees. This feature allows a comfortable cruise at high angles of attack that reduces the required wing surface also reducing the aerodynamic drag of the wing. Flight at high angles of attack with low induced drag is possible because Cora has a very high aspect ratio wing. The angle between the wing and the fuselage is also beneficial because turning on the VTOL propellers in flight produces a thrust which has a component opposed to the flight direction, allowing a smooth deceleration, and transition between cruise and vertical landing.

\subsection{Vectored Thrust}

To evaluate the vectored thrust eVTOL category, the Lilium Jet has been selected. The geometric dimensions have been estimated from the image of the first flight test of the prototype (Figure 8 and Table 8).

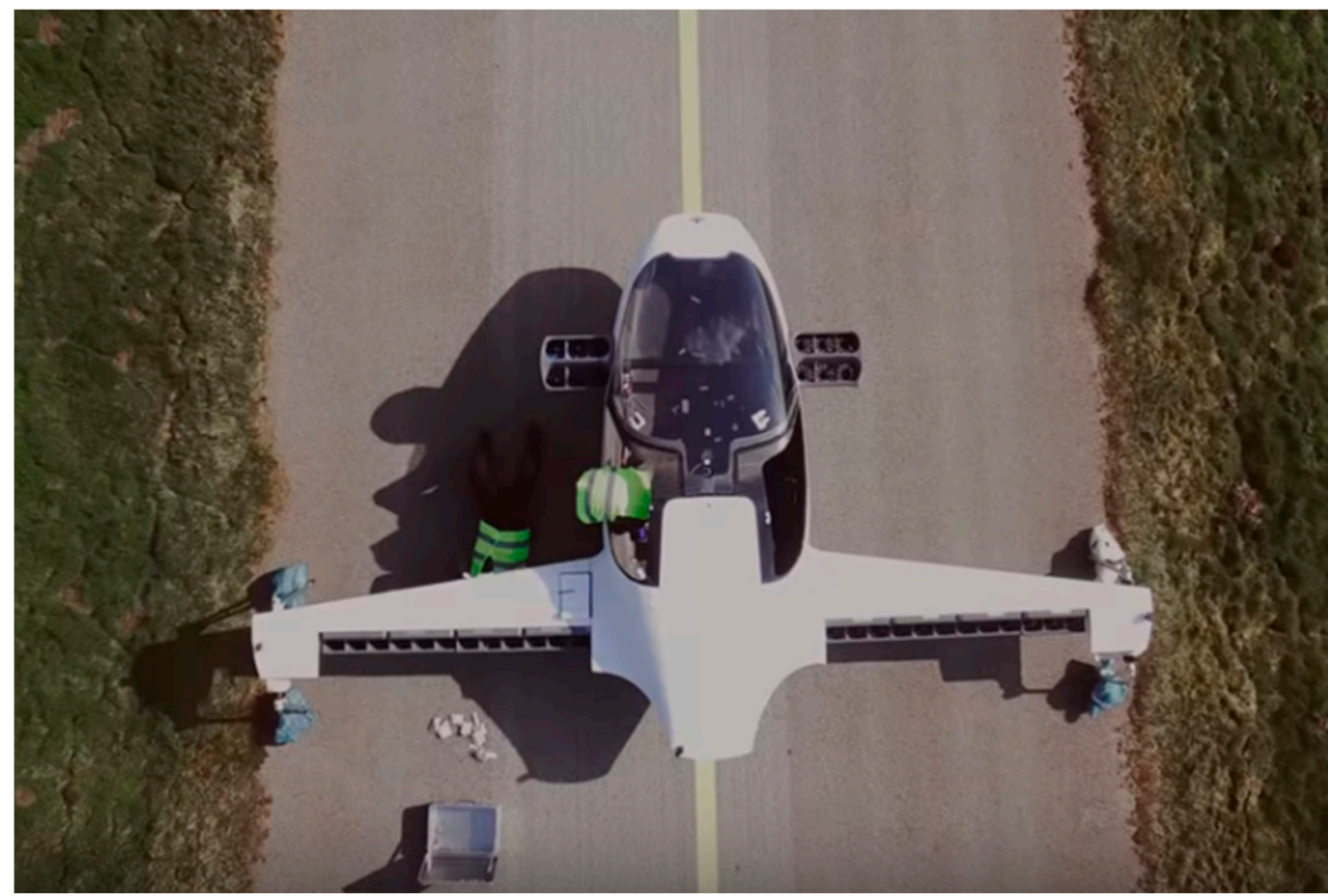

Figure 8. Lilium Jet geometry [13].

Table 8. Lilium Jet geometry

\begin{tabular}{lll}
\hline Fuselage width & $1.4 \mathrm{~m}$ & Estimated from Figure 8 \\
Fuselage length & $3.6 \mathrm{~m}$ & Estimated from Figure 8 \\
Wingspan & $6 \mathrm{~m}$ & Estimated from Figure 8 \\
Root chord & $0.78 \mathrm{~m}$ & Estimated from Figure 8 \\
Tip chord & $0.42 \mathrm{~m}$ & Estimated from Figure 8 \\
Man lying on the tarmac & $1.52 \mathrm{~m}$ & Estimated from Figure 8 \\
Suitcase & $0.46 \mathrm{~m}$ & Estimated from Figure 8 \\
Fans diameter & $0.15 \mathrm{~m}$ & Estimated from Figure 8 \\
Number of fans & 36 & From Figure 8 \\
\hline
\end{tabular}

The man lying on the tarmac and the suitcase have been measured to crosscheck the validity of the estimated measures. 
The total mass has been assumed $490 \mathrm{~kg}$ because this is less than the maximum takeoff weight for the ultralight aircraft category in Europe $(450+45 \mathrm{~kg})[48,49]$. The battery mass has been estimated at $240 \mathrm{~kg}$, with a battery mass to total mass ratio of $49 \%$. These results are presented in Table 9.

Table 9. Lilium Jet mass and battery data.

\begin{tabular}{lll}
\hline Total mass & $490 \mathrm{~kg}$ & Assumed \\
Power required to hover & $187 \mathrm{~kW}$ & Computed \\
Battery energy specific density & $157 \mathrm{Wh} / \mathrm{kg}$ & Assumed [36] \\
Battery power density & $735 \mathrm{~W} / \mathrm{kg}$ & Assumed [36] \\
Battery mass & $240 \mathrm{~kg}$ & Computed \\
Total battery energy & $38 \mathrm{kWh}$ & Computed \\
Battery mass to total mass ratio & $49 \%$ & Computed \\
\hline
\end{tabular}

The hover performances have been computed using the disk actuator theory modified for ducted fans [50]. The power required to hover is:

$$
P=\sqrt{\frac{\left(\frac{T}{T i}\right)^{3}}{2 \rho A}}
$$

where $T i=1.26$ is the thrust increase for ducted fans, $T$ is the thrust required or the weight of the vehicle and $A$ is the disk actuator area of the vertical thrust system. The sea level air density $\rho=1.225 \mathrm{~kg} / \mathrm{m}^{3}$ and gravity acceleration $g=9.8 \mathrm{~m} / \mathrm{s}^{2}$ have been used. The results are listed in Table 10. The power required found is $187 \mathrm{~kW}$ and the maximum power available with $240 \mathrm{~kg}$ of batteries and a specific power of $735 \mathrm{~W} / \mathrm{kg}$ is $176 \mathrm{~kW}$. This means that, with the assumptions made, the Tesla batteries considered are not enough to power the Lilium jet. It requires batteries with a higher specific power.

Table 10. Lilium Jet hover performances.

\begin{tabular}{ll}
\hline Energy for $1 \mathrm{~min}$ of hover & $3.12 \mathrm{kWh}$ \\
Total hover time & $12.1 \mathrm{~min}$ \\
Disk loading & $7500 \mathrm{~N} / \mathrm{m}^{2}$ \\
\hline
\end{tabular}

Prandtl's lifting line theory was used to compute the wing's lift and drag. The drag produced by the fuselage and by the forward fans has then been added. The resulting drag polar is:

$$
C_{D}=0.0163+0.058 \cdot C_{L}^{2}
$$

Applying Equations (11) to (14), the speed of maximum $L / D$ is $230 \mathrm{~km} / \mathrm{h}$ and the maximum $L / D$ is 16.3. The theoretical range, computed with Equation (13) [32], is $380 \mathrm{~km}$. Limiting the depth of discharge to $70 \%$, improving the cruise speed to save time to $250 \mathrm{~km} / \mathrm{h}$, and considering takeoff and landing the range decreases to $203 \mathrm{~km}$. The flight time is $48 \mathrm{~min}$.

Lilium is now developing a five-seater version of its eVTOL (Figure 9). 


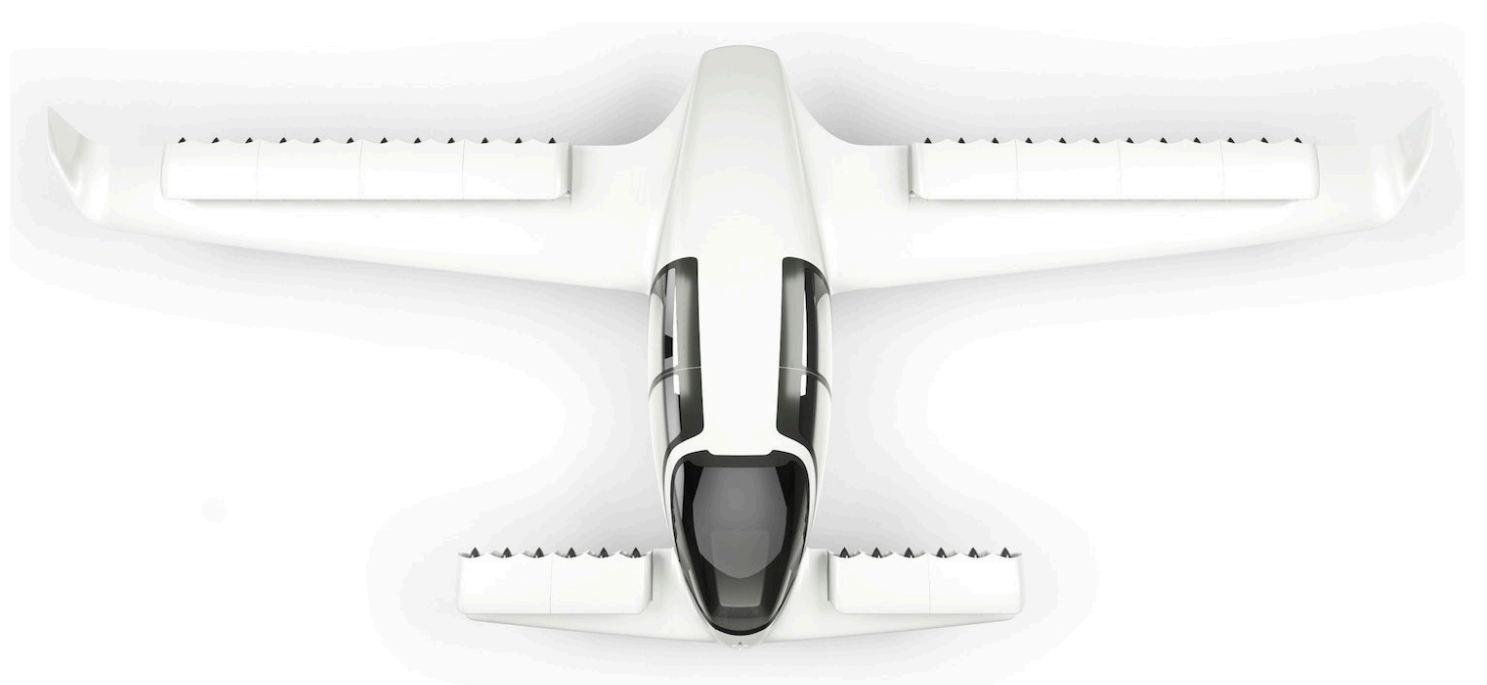

Figure 9. Lilium jet five-seater geometry.

Performing the same procedure for this vehicle, the estimated values are $12 \mathrm{~m}$ wingspan, $0.28 \mathrm{~m}$ fans diameter, $1700 \mathrm{~kg}$ total mass, and $900 \mathrm{~kg}$ battery mass. The disk loading of this vehicle is the same as the two-seater jet, the practical range with $70 \%$ depth of discharge and a cruise speed of $290 \mathrm{~km} / \mathrm{h}$ is $245 \mathrm{~km}$, and the total flight time is $55 \mathrm{~min}$.

\subsection{Reference Mission Performance}

The time and energy required by the three eVTOLs to perform the three reference missions have been computed. Each mission consists of:

- $\quad 15 \mathrm{~s}$ of takeoff at hover power;

- $\quad$ acceleration at $2 \mathrm{~m} / \mathrm{s}^{2}$ from zero forward speed to cruise speed at hover power;

- cruise flight;

- deceleration at $-2 \mathrm{~m} / \mathrm{s}^{2}$ from cruise speed to zero forward speed at hover power;

- $15 \mathrm{~s}$ of landing at hover power.

The results are presented in Tables 11-15.

Table 11. Data used in the computations for the reference mission performance.

\begin{tabular}{llll}
\hline & E-Hang 184 & Kitty Hawk Cora & Lilium \\
\hline Cruise power & $34.6 \mathrm{~kW}$ & $63 \mathrm{~kW}$ & $28 \mathrm{~kW}$ \\
Cruise speed & $100 \mathrm{~km} / \mathrm{h}$ & $180 \mathrm{~km} / \mathrm{h}$ & $252 \mathrm{~km} / \mathrm{h}$ \\
Takeoff and landing power & $42.1 \mathrm{~kW}$ & $228 \mathrm{~kW}$ & $187 \mathrm{~kW}$ \\
Total battery energy & $14.4 \mathrm{kWh}$ & $63 \mathrm{kWh}$ & $38 \mathrm{kWh}$ \\
\hline
\end{tabular}

Table 12. Takeoff, landing, acceleration, and deceleration.

\begin{tabular}{llll}
\hline & E-Hang 184 & Cora & Lilium \\
\hline Takeoff and landing time & $30 \mathrm{~s}$ & $30 \mathrm{~s}$ & $30 \mathrm{~s}$ \\
Takeoff and landing energy & $0.35 \mathrm{kWh}$ & $1.9 \mathrm{kWh}$ & $1.6 \mathrm{kWh}$ \\
Acceleration/deceleration & $2 \mathrm{~m} / \mathrm{s}^{2}$ & $2 \mathrm{~m} / \mathrm{s}^{2}$ & $2 \mathrm{~m} / \mathrm{s}^{2}$ \\
Acceleration time & $14 \mathrm{~s}$ & $25 \mathrm{~s}$ & $35 \mathrm{~s}$ \\
Acceleration energy & $0.16 \mathrm{kWh}$ & $1.58 \mathrm{kWh}$ & $1.82 \mathrm{kWh}$ \\
Acceleration/deceleration distance & $193 \mathrm{~m}$ & $625 \mathrm{~m}$ & $1225 \mathrm{~m}$ \\
Deceleration time & $14 \mathrm{~s}$ & $25 \mathrm{~s}$ & $35 \mathrm{~s}$ \\
Deceleration energy & $0.16 \mathrm{kWh}$ & $1.58 \mathrm{kWh}$ & $1.82 \mathrm{kWh}$ \\
Total time for takeoff, landing, acceleration, and deceleration & $1 \mathrm{~min}$ & $1.3 \mathrm{~min}$ & $1.7 \mathrm{~min}$ \\
Total energy for takeoff, landing, acceleration, and deceleration & $0.7 \mathrm{kWh}$ & $5.1 \mathrm{kWh}$ & $5.2 \mathrm{kWh}$ \\
\hline
\end{tabular}


Table 13. Mission 1: $7 \mathrm{~km}$ urban mission.

\begin{tabular}{llll}
\hline & E-Hang 184 & Kitty Hawk Cora & Lilium \\
\hline Cruise distance & $6.6 \mathrm{~km}$ & $5.8 \mathrm{~km}$ & $4.6 \mathrm{~km}$ \\
Cruise time & $3.9 \mathrm{~min}$ & $2.0 \mathrm{~min}$ & $1.1 \mathrm{~min}$ \\
Cruise energy & $2.3 \mathrm{kWh}$ & $2.0 \mathrm{kWh}$ & $0.5 \mathrm{kWh}$ \\
\hline Total time & $4.9 \mathrm{~min}$ & $3.3 \mathrm{~min}$ & $2.8 \mathrm{~min}$ \\
Total energy & $3.0 \mathrm{kWh}$ & $7.1 \mathrm{kWh}$ & $5.7 \mathrm{kWh}$ \\
\hline
\end{tabular}

Table 14. Mission 2: $30 \mathrm{~km}$ extra-urban mission.

\begin{tabular}{llll}
\hline & E-Hang 184 & Kitty Hawk Cora & Lilium \\
\hline Cruise distance & $29.6 \mathrm{~km}$ & $28.8 \mathrm{~km}$ & $27.6 \mathrm{~km}$ \\
Cruise time & $17.7 \mathrm{~min}$ & $9.6 \mathrm{~min}$ & $6.6 \mathrm{~min}$ \\
Cruise energy & $10.2 \mathrm{kWh}$ & $10.1 \mathrm{kWh}$ & $3.1 \mathrm{kWh}$ \\
\hline Total time & $18.7 \mathrm{~min}$ & $10.9 \mathrm{~min}$ & $8.2 \mathrm{~min}$ \\
Total energy & $10.9 \mathrm{kWh}$ & $15.2 \mathrm{kWh}$ & $8.3 \mathrm{kWh}$ \\
\hline
\end{tabular}

Table 15. Mission 3: $100 \mathrm{~km}$ long-range mission.

\begin{tabular}{llll}
\hline & E-Hang 184 & Kitty Hawk Cora & Lilium \\
\hline Cruise distance & - & $98.8 \mathrm{~km}$ & $97.6 \mathrm{~km}$ \\
Cruise time & - & $33.0 \mathrm{~min}$ & $23.2 \mathrm{~min}$ \\
Cruise energy & - & $34.6 \mathrm{kWh}$ & $10.9 \mathrm{kWh}$ \\
\hline Total time & - & $34.3 \mathrm{~min}$ & $24.9 \mathrm{~min}$ \\
Total energy & - & $39.7 \mathrm{kWh}$ & $16.1 \mathrm{kWh}$ \\
\hline
\end{tabular}

\section{Discussion}

The three configurations examined have been compared. Their hover and cruise flight parameters are presented in Table 16 and their performances for the three reference missions are presented in Table 17, Figures 10 and 11.

Table 16. Performances comparison.

\begin{tabular}{llll}
\hline & E-Hang 184 & Kitty Hawk Cora & Lilium \\
\hline Disk loading $\left(\mathrm{N} / \mathrm{m}^{2}\right)$ & 440 & 880 & 7500 \\
Total hover time $(\mathrm{min})$ & 20.5 & 16.5 & 12.1 \\
Cruise speed $(\mathrm{km} / \mathrm{h})$ & 100 & 180 & 252 \\
Practical range $(\mathrm{km})$ & 42 & 107 & 203 \\
Flight time $(\mathrm{min})$ & 25 & 36 & 48 \\
\hline
\end{tabular}

Table 17. Summary of the energy and time required for the three reference missions.

\begin{tabular}{lccc}
\hline & E-Hang 184 & Kitty Hawk Cora & Lilium \\
\hline $7 \mathrm{~km}$ urban mission time & $4.9 \mathrm{~min}$ & $3.3 \mathrm{~min}$ & $2.8 \mathrm{~min}$ \\
$7 \mathrm{~km}$ urban mission energy & $3.0 \mathrm{kWh}$ & $7.1 \mathrm{kWh}$ & $5.7 \mathrm{kWh}$ \\
\hline $30 \mathrm{~km}$ extra-urban mission time & $18.7 \mathrm{~min}$ & $10.9 \mathrm{~min}$ & $8.2 \mathrm{~min}$ \\
$30 \mathrm{~km}$ extra-urban mission energy & $10.9 \mathrm{kWh}$ & $15.2 \mathrm{kWh}$ & $8.3 \mathrm{kWh}$ \\
\hline $100 \mathrm{~km}$ long-range mission time & - & $34.3 \mathrm{~min}$ & $24.9 \mathrm{~min}$ \\
$100 \mathrm{~km}$ long-range mission energy & - & $39.7 \mathrm{kWh}$ & $16.1 \mathrm{kWh}$ \\
\hline
\end{tabular}




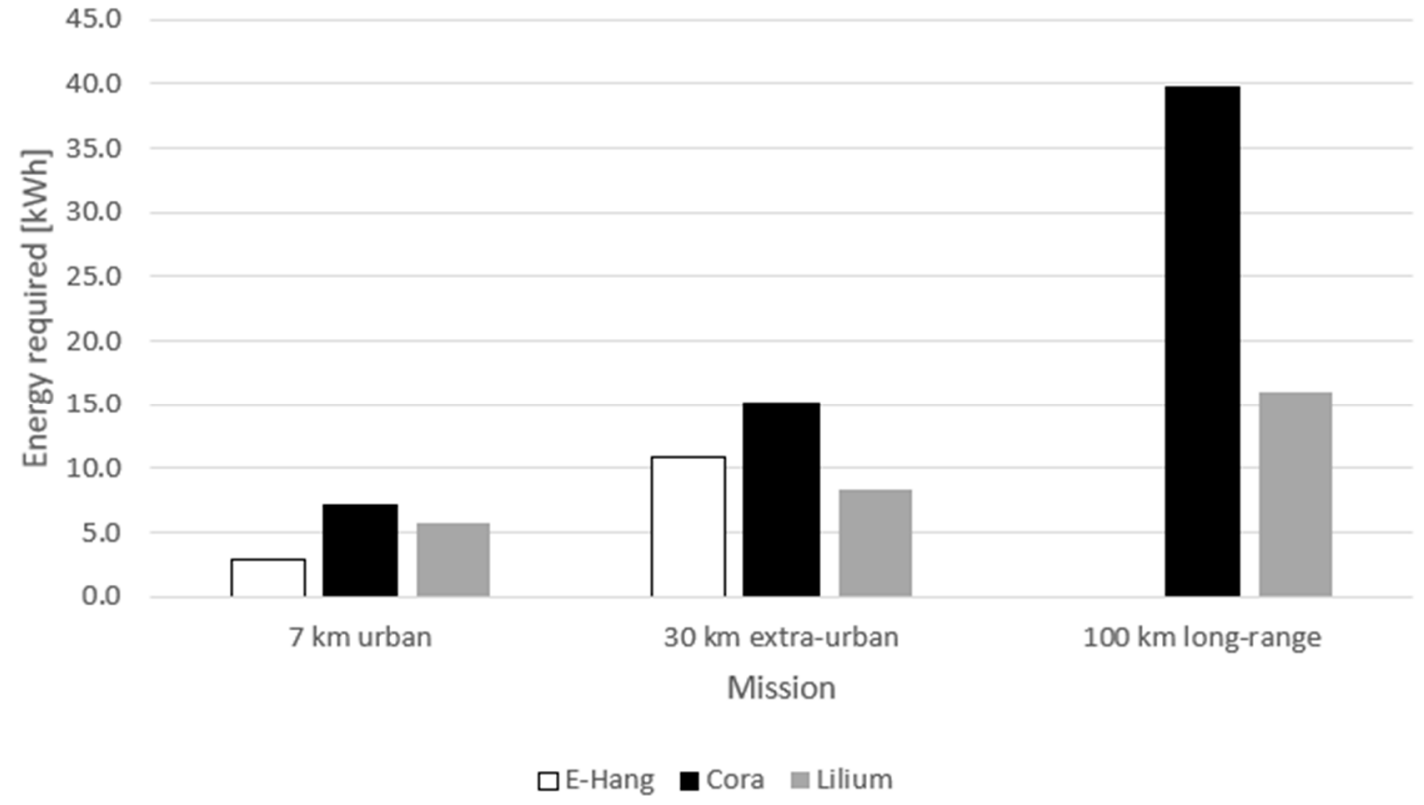

Figure 10. Energy required for the three reference missions.

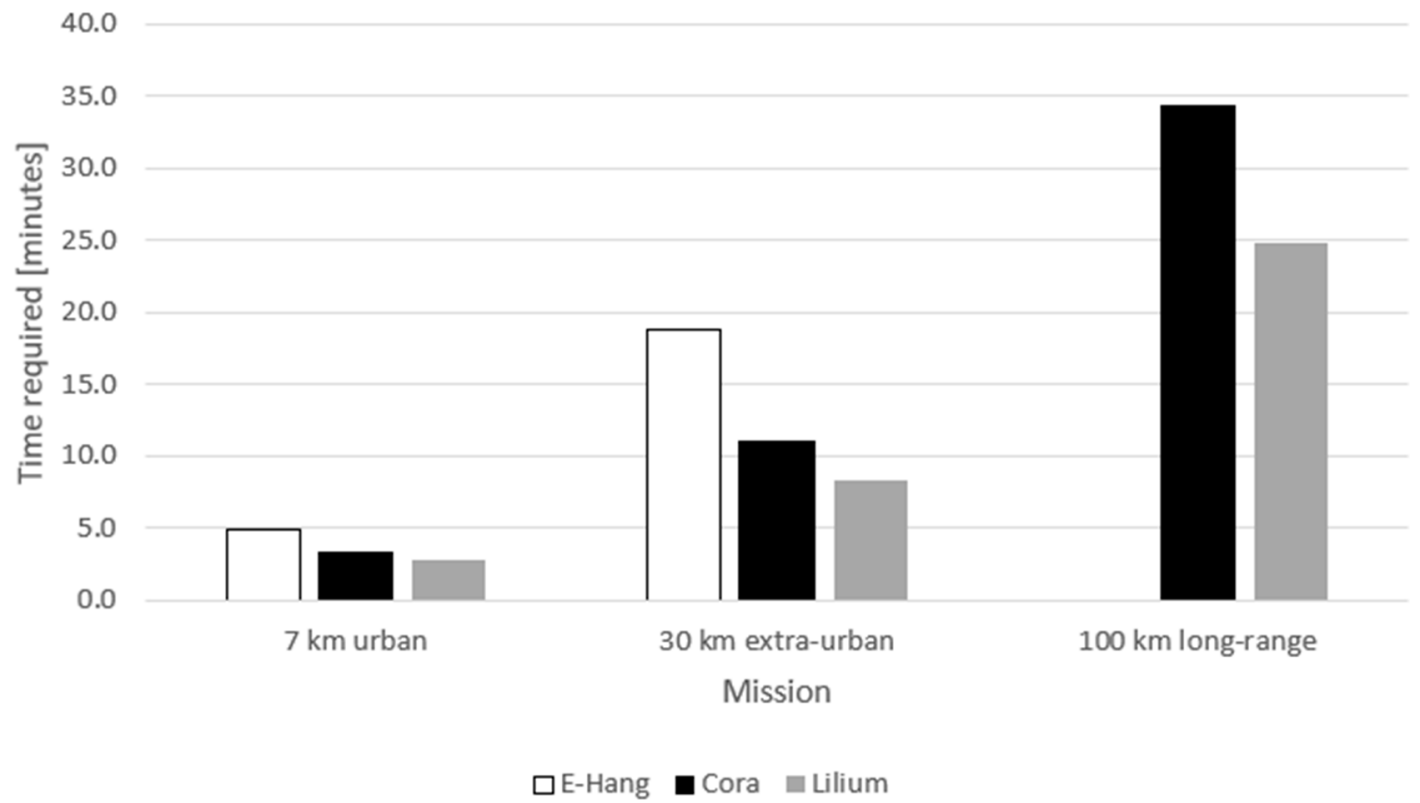

Figure 11. Time required for the three reference missions.

Table 16 shows that the multirotor configuration represented by the E-Hang 184 is the best suited to hover flight while Lilium is the best suited to cruise flight. The lift + cruise Cora is a compromise. It has less range and flight speed than Lilium but good hover performances comparable to the wingless multirotor configuration.

The $7 \mathrm{~km}$ urban mission is completed in $4.9 \mathrm{~min}$ by E-Hang, $3.3 \mathrm{~min}$ by Cora, and $2.8 \mathrm{~min}$ by Lilium. E-Hang requires $3 \mathrm{kWh}$, Cora $7.1 \mathrm{kWh}$, and Lilium $5.7 \mathrm{kWh}$. The $30 \mathrm{~km}$ extra-urban mission is completed in $18.7 \mathrm{~min}$ by E-Hang, $10.9 \mathrm{~min}$ by Cora, and $8.2 \mathrm{~min}$ by Lilium. E-Hang requires $10.9 \mathrm{kWh}$, Cora $15.2 \mathrm{kWh}$, Lilium $8.3 \mathrm{kWh}$. The $100 \mathrm{~km}$ long-range mission cannot be completed by E-Hang and is almost Cora's computed maximum range. It is completed in $34.3 \mathrm{~min}$ by Cora and $24.9 \mathrm{~min}$ by Lilium. Cora requires $39.7 \mathrm{kWh}$ and Lilium 16.1.

The urban mission comparison shows that multirotors require less energy for short-range missions. In the extra-urban mission, the cruise phase is as important as the hover phase, and the energy required 
by the three configurations is comparable. In the long-range mission, cruise efficiency is more important. E-hang's range is insufficient to complete it. Cora's parasitic drag caused by the pylons and vertical thrust propellers increases the power required in cruise. Its cruise speed is less than Lilium's and the energy required is more.

Lilium's hover is so power demanding that it requires batteries with higher specific power than the Tesla batteries considered for the computations. This means that the aerodynamic advantages of this configuration are balanced by higher demands on the batteries and on the power electronics.

More practical reasons might influence which eVTOL configuration will be adopted more rapidly in the future. The multirotor configuration seems to be closer to the market and less complex than the lift + cruise and the electric jet. However, the range advantage of the latter two enables missions impossible to the multirotor configuration.

\section{Conclusions}

Different configurations of turboshaft powered VTOLs tested in the fifties and sixties have been discussed in the introduction detailing advantages, disadvantages, and problems of each one. The recent eVTOL prototypes categories have then been presented under the classification proposed by the American Helicopter Society. The performances of the three main eVTOL configurations have been evaluated estimating five main parameters, the energy and the time required to complete three reference missions. The performances of the E-Hang 184 have been estimated for the multirotor configuration, the Kitty Hawk Cora was selected for the lift plus cruise configuration and the Lilium jet represented the electric jet configuration. This analysis showed that the best eVTOL configuration depends on the mission. Short-range missions are best performed by multirotors because they have better hover performances. Long-range missions cannot be accomplished by multirotors because their range is not enough.

Author Contributions: Conceptualization, A.B. and E.C.; Methodology, A.B. and E.C.; Software, A.B.; Validation, A.B. and E.C.; Formal Analysis, A.B. and E.C.; Data Curation, A.B. and E.C.; Writing-Original Draft Preparation, A.B.; Writing-Review \& Editing, A.B. and E.C.; Supervision, E.C.; Project Administration, E.C.

Funding: This research received no external funding.

Conflicts of Interest: The authors declare no conflict of interest.

\section{References}

1. Moore, M. NASA Puffin Electric Tailsitter VTOL Concept. In Proceedings of the 10th AIAA Aviation Technology, Integration, and Operations (ATIO) Conference, Fort Worth, TX, USA, 13-15 September 2010.

2. Kitty Hawk. Available online: https://kittyhawk.aero/ (accessed on 20 December 2018).

3. Hirschberg, M. Stand on the Shoulders of Giants. Vertiflite. 2019. Available online: http://evtol.news/2019/ 01/02/stand-on-the-shoulders-of-giants / (accessed on 28 January 2019).

4. Hirschberg, M. Electric VTOL is Taking Off. Vertiflite. 2018. Available online: http:/ / evtol.news/2018/08/ 30/electric-vtol-is-taking-off-beware-the-hyper-hype-cycle/ (accessed on 28 January 2019).

5. Smith, J.C.; Viken, J.K.; Guerreiro, N.M.; Dollyhigh, S.M.; Fenbert, J.W.; Hartman, C.L.; Kwa, T.K.; Moore, M. Projected demand and potential impacts to the National Airspace System of autonomous, electric, on-demand small aircraft. In Proceedings of the 12th AIAA Aviation Technology, Integration, and Operations (ATIO) Conference, Indianapolis, IN, USA, 17-19 September 2012.

6. Patterson, M.; German, B.; Moore, M. Performance Analysis and Design of On-Demand Electric Aircraft Concepts. In Proceedings of the AIAA ATIO Conference, Indianapolis, IN, USA, 17-19 September 2012.

7. Fredericks, W.J.; Moore, M.; Busan, R.C. Benefits of Hybrid-Electric Propulsion to Achieve 4x Cruise Efficiency for a VTOL UAV. In Proceedings of the 2013 International Powered Lift Conference (AIAA AVIATION Forum), Los Angeles, CA, USA, 12-14 August 2013.

8. Moore, M.; Fredericks, W.J. Misconceptions of Electric Aircraft and their Emerging Aviation Markets. In Proceedings of the 52nd Aerospace Sciences Meeting (AIAA SciTech Forum), National Harbor, MD, USA, 13-17 January 2014. [CrossRef] 
9. Borer, N.K.; Patterson, M.D.; Viken, J.K.; Moore, M.; Bevirt, J.; Stoll, A.M.; Gibson, A.R. Design and Performance of the NASA SCEPTOR Distributed Electric Propulsion Flight Demonstrator. In Proceedings of the 16th AIAA Aviation Technology, Integration, and Operations Conference (AIAA AVIATION Forum), Washington, DC, USA, 13-17 June 2016.

10. McDonald, R.A. Electric Propulsion Modeling for Conceptual Aircraft Design. In Proceedings of the 52nd Aerospace Sciences Meeting (AIAA SciTech Forum), National Harbor, MD, USA, 13-17 January 2014.

11. Holden, J.; Goel, N. Uber Elevate. Available online: https://www.uber.com/elevate.pdf (accessed on 28 January 2019).

12. Kitty Hawk Aero. Available online: https:/ / kittyhawk.aero (accessed on 28 January 2019).

13. Lilium. Available online: https:/ /lilium.com (accessed on 28 January 2019).

14. Joby Aviation. Available online: https://www.jobyaviation.com (accessed on 28 January 2019).

15. E-Hang 184. Available online: http:/ / www.ehang.com/ehang184/specs (accessed on 20 December 2018).

16. Vertipedia. Available online: vertipedia.vtol.org (accessed on 11 November 2017).

17. Anderson, S.B. Historical Overview of V/STOL Aircraft Technology; NASA Technical Memorandum 81280; Ames Research Center: Moffett Field, CA, USA, 1981.

18. Margason, R.J. Review of Propulsion-Induced Effects on Aerodynamics of Jet/Stol Aircraft; NASA Technical Note D-5617; Washington, DC, USA, 1970. Available online: https://ntrs.nasa.gov/archive/nasa/casi.ntrs.nasa. gov/19700008938.pdf (accessed on 28 January 2019).

19. Harrier Jump Jet, Wikipedia. Available online: https://en.wikipedia.org/wiki/Harrier_Jump_Jet (accessed on 28 January 2019).

20. McSwain, R.G.; Glaab, L.J.; Theodore, C.R. Greased Lightning (GL-10) Performance Flight Research; NASA TM-2017-219794; Washington, DC, USA, 2017. Available online: https://ntrs.nasa.gov/archive/nasa/casi. ntrs.nasa.gov/20180000765.pdf (accessed on 28 January 2019).

21. Dassault Mirage III V, Wikipedia. Available online: https:/ / en.wikipedia.org/wiki/Dassault_Mirage_IIIV (accessed on 28 January 2018).

22. eVTOL Classifications. Available online: http:/ / evtol.news/classifications (accessed on 28 January 2019).

23. Aurora Aero. Available online: www.aurora.aero/lightningstrike (accessed on 28 January 2019).

24. Blain, L. Joby's Wild 16-Rotor Convertible Aircraft for Long-Range, High-Speed, Electric VTOL Commuting. Available online: https:/ / newatlas.com/joby-s2-tilt-rotor-vtol-multirotor-aircraft-concept/40662/ (accessed on 28 January 2019).

25. Electric VTOL News. Available online: http://evtol.news/aircraft/zee-aero (accessed on 20 December 2018).

26. Electric VTOL News. Available online: http:/ / evtol.news/aircraft/aurora (accessed on 20 December 2018).

27. Electric VTOL News. Available online: http://evtol.news/aircraft/kitty-hawk-cora (accessed on 20 December 2018).

28. Electric VTOL News. Available online: http:/ / evtol.news/aircraft/ehang (accessed on 20 December 2018).

29. Volocopter 2X, Wikipedia. Available online: https://en.wikipedia.org/wiki/Volocopter_2X (accessed on 20 December 2018).

30. Fingas, J. Kitty Hawk's Flyer Isn't the Flying Car You Were Promised. Available online: https://www. engadget.com/2017/04/24/kitty-hawk-flying-car (accessed on 20 December 2018).

31. Electric VTOL News. Available online: http:/ / evtol.news/aircraft/aquinea-volta (accessed on 20 December 2018).

32. Bacchini, A.; Cestino, E. Electric VTOL conceptual design general considerations. Proc. iMeche Part G J. Aerosp. Eng. 2018, submitted.

33. Seddon, J. Basic Helicopter Aerodynamics, 2nd ed.; Blackwell Science: Hoboken, NJ, USA, 1990; p. 16.

34. Hepperle, M. Electric Flight-Potential and Limitations; German Aerospace Center, DLR: Braunschweig, Germany, 2012.

35. Hoerner, S.F. Fluid-Dynamic Drag; Hoerner Fluid Dynamics: Brick Town, NJ, USA, 1965.

36. Tesla Model S, Wikipedia. Available online: https://en.wikipedia.org/wiki/Tesla_Model_S (accessed on 20 December 2018).

37. Linden, D.; Reddy, T.B. Handbook of Batteries, 3rd ed.; McGraw-Hill: New York, NY, USA, 2002.

38. Leishman, G.; Syal, M. Figure of Merit Definition for Coaxial Rotors. J. Am. Helicopter Soc. 2008, 53, $290-300$. [CrossRef] 
39. Coleman, C.P. A Survey of Theoretical and Experimental Coaxial Rotor Aerodynamic Research; NASA Technical Paper 3675; National Aeronautics and Space Administration: Washington, DC, USA, 1997.

40. Bramwell, R.S. Bramwell's Helicopter Dynamics, 2nd ed.; Butterworth-Einemann: Oxford, UK, 2001.

41. Di Franco, C.; Buttazzo, G. Energy-Aware Coverage Path Planning of UAVs. 2015 IEEE International Conference on Autonomous Robot Systems and Competitions, Villa Real, Portugal, 8-10 April 2015.

42. Electric VTOL News, Meet Cora by Mike Hirschberg. Available online: http:/ / evtol.news/2018/04/19/ meet-cora (accessed on 20 December 2018).

43. Selig, M.; Maughmer, M.D.; Somers, D.M. Natural-Laminar-Flow Airfoil for General-Aviation Applications. J. Aircr. 1995, 32, 710-715. [CrossRef]

44. Airfoil Tools. Available online: http://airfoiltools.com/airfoil/details?airfoil=nlf0115-il (accessed on 28 January 2019).

45. Xfoil. Available online: https://web.mit.edu/drela/Public/web/xfoil/ (accessed on 28 January 2019).

46. Jenkinson, L.R. Civil Jet Aircraft Design, 1st ed.; Arnold, A Member of the Hodder Headline Group: London, UK, 1999.

47. Anderson, J.D. Aircraft Performance and Design; McGraw-Hill: New York, NY, USA, 1999.

48. Ultralight Glider. Available online: http://www.ultralight-glider.fr/en/european-exemptions (accessed on 20 December 2018).

49. Official Journal of the European Union. Available online: https://eur-lex.europa.eu/legal-content/EN/ TXT/PDF/?uri=OJ:L:2018:212:FULL\&from=FR (accessed on 21 December 2018).

50. Tognaccini, R. Lezioni di Aerodinamica dell'ala Rotante; Università Degli Studi di Napoli: Napoli, Italy, 2008.

(C) 2019 by the authors. Licensee MDPI, Basel, Switzerland. This article is an open access article distributed under the terms and conditions of the Creative Commons Attribution (CC BY) license (http:/ / creativecommons.org/licenses/by/4.0/). 